JURNAL KETAHANAN NASIONAL

Vol. 26, No. 2, Agustus 2020, Hal 132-154

DOI:http://dx.doi.org/ 10.22146/jkn.56318

ISSN:0853-9340(Print), ISSN:2527-9688(Online)

Online sejak 28 Desember 2015 di :http://jurnal.ugm.ac.id/JKN

VOLUME 26

No. 2, Agustus 2020

Halaman 132-154

\title{
Pemerintah Indonesia Menghadapi Bencana Nasional Covid -19 Yang Mengancam Ketahanan Nasional
}

\author{
Eko G. Samudro \\ Universitas Pertahanan \\ email: ekogsamudro@gmail.com \\ M. Adnan Madjid \\ Universitas Pertahanan \\ email:adnan.madjid@idu.ac.id
}

Dikirim: 26-05-2020; Direvisi: 10-08-2020; Diterima; 27-08-2020

\begin{abstract}
The outbreak of Corona. Virus Disease 2019. (Covid-19) had had a wide-ranging impact on the conditions of security and public order in Indonesia and national resilience. This had also been responded by the World Health Organization (WHO) by establishing the status of a global pandemic in Covid-19 given the negative impact that striked many countries in the world.

With qualitative research methods, information was obtained from relevant informants that, with existing policies, the Indonesian government had carried out various efforts in the framework of the detection, prevention and control of this Covid-19. Some of them were with the Presidential Decree No. 9 of 2020 concerning Amendment to Presidential Decree No. 7 of 2020 concerning the Task Force for the Acceleration of Handling Covid-19, Government Regulation of the Republic of Indonesia No. 21 of 2020 concerning Large-Scale Social Restrictions (PSBB) in the framework of Accelerating Handling of Covid-19 and Presidential Decree No. 12 of 2020 concerning Determination of Non-natural Disasters of the spread of Covid-19 as a National Disaster.

From the group policy analysis model, it was found that in the unstable condition of the community in the midst of this pandemic, the PSBB policy was supported by the existence of the Task Force as an appropriate step in the handling of Covid-19 in Indonesia compared to the lockdown option which could have a domino effect on the condition of the nation. In addition, this paper also simulated government policy options by implementing a policy pattern for implementing rapid tests, quarantine and hospital operations for handling Covid-19 (Option $C$ ) and physical distancing / social distancing policies with patterns of working from home (Option D) that could provide the result of a decrease in the number of Covid-19 cases in Indonesia.
\end{abstract}

\section{Keywords : Indonesian Government; National Disaster; Global Pandemic of Covid-19; National Resilience.}

\footnotetext{
ABSTRAK

Tersebarnya Corona Virus Disease 2019 (Covid-19) telah memberikan pengaruh pada kondisi keamanan dan ketertiban masyarakat di Indonesia dan ketahanan nasional. Hal ini sudah ditanggapi oleh World Health Organization (WHO) dengan menetapkan status pandemi global pada Covid-19 mengingat dampak negatif yang menyerang banyak negara di dunia.

Metode penelitian kualitatif digunakan guna mendapatkan informasi dari narasumber terkait bahwa, dengan kebijakan yang ada, pemerintah Indonesia telah menjalankan berbagai upaya dalam rangka deteksi, pencegahan dan
} 
penanggulangan Covid-19 ini. Beberapa di antaranya adalah adanya Keppres No. 9 tahun 2020 tentang Perubahan atas Keppres No. 7 Tahun 2020 tentang Gugus Tugas Percepatan Penanganan Covid-19, Peraturan Pemerintah Republik Indonesia No. 21 tahun 2020 tentang Pembatasan Sosial Bersakala Besar (PSBB) dalam rangka Percepatan Penanganan Covid-19 dan Keppres No. 12 tahun 2020 tentang Penetapan Bencana Non-alam penyebaran Covid-19 sebagai Bencana Nasional.

Model analisis kebijakan kelompok menemukan bahwa dalam kondisi masyarakat yang tidak stabil di tengah pandemi ini, kebijakan PSBB didukung dengan adanya Gugus Tugas tersebut merupakan langkah yang tepat dalam rangka penanganan Covid-19 di Indonesia dibandingkan opsi lockdown yang bisa memberikan efek domino pada kondisi bangsa. Selain itu, tulisan ini juga mensimulasikan opsi kebijakan pemerintah dengan menerapkan pola kebijakan pelaksanaan rapid test, karantina maupun operasional RS untuk penanganan Covid-19 (Opsi C) dan kebijakan physical distancing / social distancing dengan pola bekerja dari rumah (Opsi D) yang dapat memberikan hasil penurunan jumlah kasus Covid-19 di Indonesia.

\section{Kata Kunci: Pemerintah Indonesia; Bencana Nasional; Pandemi Global Covid-19; Ketahanan Nasional.}

\section{PENGANTAR}

Wabah penyakit yang menerpa Indonesia menjadi bentuk ancaman nyata bagi keselamatan bangsa. Sebagai salah satu ancaman faktual, wabah ini termasuk dalam potensi bencana, yang dijelaskan pada UU No. 24 Tahun 2007 tentang Penanggulangan Bencana. Penyebaran virus corona (Covid-19) adalah ancaman (hazard) potensi bencana bagi kepentingan maupun kondisi ketertiban nasional, yang dalam hal ini bisa mencakup bencana alam, bencana buatan manusia ataupun gabungan dari keduanya. Pemerintah Indonesia menegaskan jika masih terdapat penularan Covid-19 sehingga membuat kasus ini masih bertambah di Indonesia sampai hari ini, seperti yang dilaporkan oleh Juru Bicara Gugus Tugas Percepatan Penanganan Covid-19. Wibowo (2020) berpendapat, melalui Gugus Tugas ini, tercatat tertambahnya jumlah kasus orang yang sembuh per minggu (26/April) menjadi 1.107 orang. Namun demikian, kasus meninggal menjadi 743 orang. Dalam hal ini, Provinsi DKI Jakarta masih menjadi wilayah dengan sebaran pasien sembuh terbanyak sebesar 335 orang, sedangkang daerah lain seperti Jawa Barat 93 orang Jawa Timur 138 orang, Sulawesi Selatan 99 orang, Bali 75 orang dan wilayah lain di Indonesia dengan total mencapai 1.107 pasien.

Berdasarkan sumber data yang sama, Kasus Covid-19 di Indonesia per-tanggal 26 April 2020 mencapai 8.882 kasus. Hal ini menandakan bahwa telah terjadi penularan virus tersebut di tengah-tengah masyarakat. Hal ini berlangsung disebabkan ada orang yang terjangkit virus namun tidak merasakan tanda-tanda sakit (Orang Tanpa Gejala atau OTG), dan tetap bisa beraktivitas. Tidak menutup kemungkinan bahwa angka ini dapat bertambah besar pada bulan Mei 2020. Juru bicara pemerintah dalam penanganan Covid-19 menegaskan kepada masyarakat untuk taat pada himbauan dari pemerintah sehingga penularan Covid-19 tidak semakin meluas. Dengan cara mentaati himbauan untuk disiplin mencuci tangan dengan sabun maupun pemakaian masker saat di luar rumah (lihat gambar 1).

Menyikapi hal tersebut, sudah dipastikan bahwa penyebaran Covid-19 di Indonesia adalah hal yang sangat luar biasa mengancam kelangsungan hidup bangsa.

Berdasarkan gambar 1 tersebut, dapat diketahui jumlah masyarakat yang terpapar Covid-19. Orang Dalam Pengawasan (ODP) berjumlah 49.361 sedangkan Pasien Dalam 
Gambar 1

Jumlah Masyarakat Terpapar Covid-19 Di Indonesia Per 25 Mei 2020

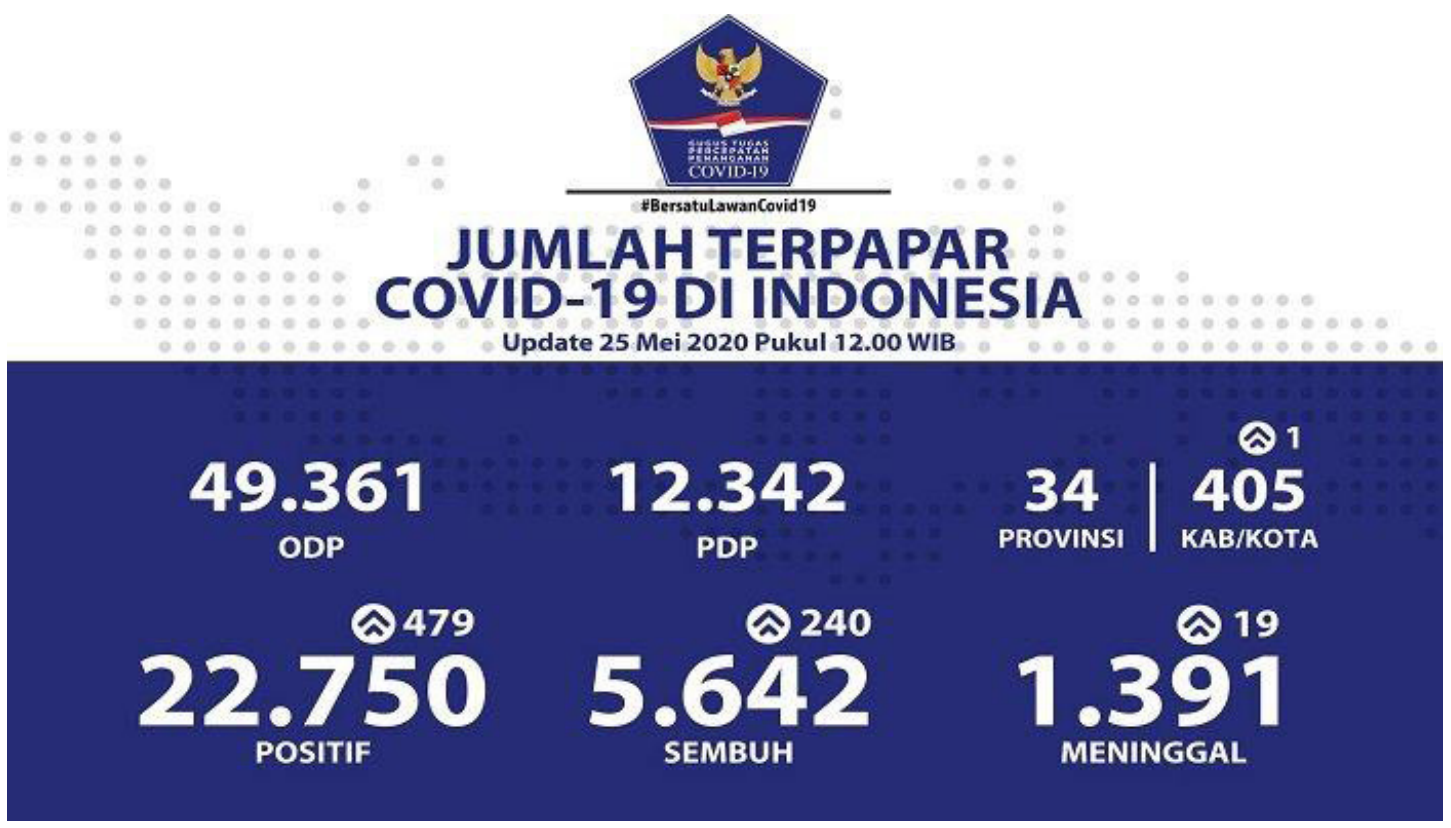

Sumber: Handayani, 2020

Pengawasan (PDP) berjumlah 12.342 orang. Jumlah orang yang dinyatakan positif mengidap Covid-19 adalah 22.750 orang, meningkat 479 kasus dari jumlah sebelumnya. Sedangkan pasien Covid-19 yang dinyatakan sembuh adalah 5.642 orang, meningkat 240 kasus dari jumlah sebelumnya dan 1.391 orang dinyatakan meninggal dunia akibat dari Covid-19 ini. Dari gambar 1 tersebut, dapat dipahami bahwa jumlah ODP yang terus meningkat akan mengkonfirmasi jumlah pasien positif Covid-19 di Indonesia. Meskipun jumlah pasien yang sembuh juga terus bertambah, tetapi fakta bahwa bertambahnya orang yang terjangkit Covid-19 di Indonesia menandakan bahwa penyebaran virus masih akan terus terjadi jika masyarakat Indonesia tidak mematuhi protokol kesehatan yang ada. Ruswandi (2020) juga menyatakan bahwa pemerintah masih cenderung kewalahan dalam mendeteksi Covid-19 ini mengingat tidak semua masyarakat Indonesia jujur dalam mendeskripsikan penyakitnya dan Orang Tanpa Gejala (OTG) yang dapat menyebarkan virus ini pada orang lain tanpa dia sadari.

Atas kondisi yang terjadi saat ini, dapat dikatakan bahwa Covid-19 ini termasuk dalam kelompok bencana yang telah menghilangkan nyawa manusia dan memberikan dampak kehidupan sosial masyarakat lainnya. WHO (2002) berpendapat tentang bencana adalah suatu peristiwa yang menggangu kondisi normal dan menyebabkan level penderitaan yang melebihi kapasitas dari komunitas yang terdampak. Berdasarkan penjelasan terkait dengan bencana sebelumnya, dapat dikatakan Covid-19 ini adalah bencana non-alam yang memberikan dampak negatif bagi kehidupan masyarakat, baik menghilangkan nyawa manusia, menghilangkan mata pencaharian masyarakat terdampak, mengganggu distribusi dan ketersediaan logistik masyarakat maupun mengganggu kondisi psikologi masyarakat itu sendiri. 
Dalam kurun waktu belakangan ini, beberapa persoalan yang muncul semakin kompleks karena krisis multi dimensional maupun bencana alam, maka bagaimanapun keadaan ini sudah tentu memerlukan perhatian dan solusi dari pemerintah dengan cepat serta akurat sehingga permasalahan yang ada di Indonesia dapat dengan sigap diatasi. Kondisi ini menempatkan pemerintah dan kementerian maupun lembaga terkait dituntut untuk menentukan pilihan-pilihan kebijakan yang cukup sulit.

Dalam menyelesaikan permasalahan yang ada diperlukan mekanisme pengambilan keputusan atas kebijakan yang sesuai, sehingga kebijakan tersebut tidak menimbulkan masalah lainnya. Diperlukan bentuk analisis yang akurat dalam pengambilan keputusan nantinya, misal dengan bantuan berbagai model maupun pendekatan yang tepat dengan persoalan yang akan diselesaikan. Agar dapat mengambil kebijakan yang tepat dengan permasalahan yang dihadapi, maka seorang pemimpin perlu mengetahui dan memahami berbagai model serta pendekatan yang bisa digunakan sebagai dasar dalam penentuan sebuah kebijakan. Dalam menyikapi kasus Penyebaran Covid 19 di Indonesia, tulisan ini bertujuan untuk menganalisis peran pemerintah Indonesia dalam menyikapi Bencana Nasional Covid-19. Dengan metode penelitian kualitatif, teknik wawancara dan studi literatur digunakan dalam pengambilan data serta menempatkan sudut pandang model analisis kebijakan kelompok yang memposisikan presiden RI sebagai penyeimbang dalam pemerintahan atas opsi kebijakan yang ada guna penanganan Covid-19 serta skema perhitungan secara kuantitatif dari pola kebijakan yang dapat diambil pemerintah Indonesia dalam menangani virus ini.

\section{PEMBAHASAN}

\section{Analisis Kebijakan Penanganan COVID-19}

Indonesia secara resmi menyatakan penyebaran wabah Covid-19 pada bulan Maret 2020 melalui pengumuman atas dua pasien pertama oleh Presiden Jokowi. Pasca pengumuman tersebut, terjadi peningkatan atas jumlah pasien positif Covid-19 di Indonesia. Pemerintah mengakui sudah mempersiapkan beberapa upaya dalam menangani virus ini, mulai dari penyekatan pintu masuk ke Indonesia di beberapa titik seperti bandara dan pelabuhan serta menyediakan fasilitas kesehatan yang memadai. Selain itu, pemerintah juga bersedia menjamin biaya pengobatan bagi masyarakat yang terinfeksi Covid-19 dan menyediakan lebih dari 100 RS di seluruh Indonesia. Akan tetapi pemerintah belum menyediakan jaminan bahwa semua alat kesehatan yang dibutuhkan guna deteksi awal telah tersedia atau masih dalam proses pengadaan.

Dalam menyikapi kasus Covid-19, pemerintah sudah mengupayakan beberapa skema terkait hubungan dengan negara tetangga. Guna mengantisipasi penyebaran Covid-19, Kementerian Luar Negeri RI menyatakan kebijakan lainnya atas perlintasan orang dari negara lain ke dalam negeri. Dijelaskan bahwa pemerintah berupaya menyikapi tulisan dari WHO mengenai perkembangan penyebaran Covid-19. Arahan Presiden RI tentang penanganan Covid-19, termasuk pelaksanaan social distancing.

Menanggapi hal ini, menempuh langkah social distancing harus disikapi sebagai salah satu langkah pencegahan penularan Covid-19, selain juga dalam rangka meminimalisir beban layanan kesehatan unutk masyarakat. Pengertian social distancin' ialah mengurangi 
sejumlah aktivitas di luar rumah serta interaksi bersama orang lain sebagai upaya mengurangi kontak langsung dengan sesama. Cara ini juga termasuk untuk menghindari tempat-tempat yang ramai dikunjungi, seperti mall, pasar, maupun keramaian lainnya. Saat penerapan social distancing, kegiatan untuk pergi ke kantor dapat menggunakan transportasi umum masih diperbolehkan, dengan menerapkan protokol kesehatan tentunya. Dalam hal ini, penumpang harus berjarak setidaknya 1,5 meter dengan sesama, meski kadangkala tidak bisa diterapkan di segala situasi. Kontak fisik langsung, seperti berjabat tangan, berpelukan karena Covid-19 menyebar lewat tetesan air liur (droplet). Langkah social distancing sudah dilaksanakan di Kota Wuhan, Provinsi Hubei, China, tempat Covid-19 awal terjadi. Ketika Covid-19 mulai menyebar, lembaga kesehatan di China sigap melarang acaraacara yang dihadiri banyak warga. Oleh karena itu, tingkat penularan dapat diturunkan, dibandingkan Iran dan Italia, yang tidak menerapkan social distancing. Selanjutnya, tak hanya social distancing diberlakukan, Wuhan juga menerapkan lockdown yang dapat memperketat pergerakan warga. Akan tetapi, banyak negara lain yang menganggap jika lockdown belum terlalu efektif menurunkan laju penyebaran Covid-19.

Berbeda dengan lockdown, social distancing sifatnya dalam berupa imbauan yang dilakukan hanya berdasar pada kesadaran tiap warga. Sebaliknya, lockdown merupakan langkah yang dilakukan pemerintah dengan paksaan untuk menutup dan mengunci sejumlah titik di area. Sampai saat ini, beberapa negara di Eropa menutup beberapa tempat umum seperti universitas, sekolah, restoran, bioskop, dan cafe, atau tempat lainnya yang ramai dikunjungi orang. Lockdown dapat dipahami sebagai situasi yang melarang warga untuk masuk pada suatu lokasi karena kondisi yang darurat. Lockdown dapat berarti bahwa suatu negara menutup perbatasannya, sehingga tidak ada orang yang masuk maupun keluar dari negaranya. Di Perancis, istilah ini dimaknai dengan menutup banyak tempat yang dianggap tidak vital, termasuk tempat pariwisata, seperti menara Eiffel, yang sudah berlaku mulai 15 Maret 2020. Sedangkan bank, apotek, supermarket, dan layanan umum lain tetap beroperasi, walaupun pembatasan diberlakukan terkait jumlah orang nya. Sama hal nya dengan Spanyol yang menerapkan lockdown, warga masih dapat membeli makanan dan obat-obatan, bahkan pergi bekerja.

Kekeliruan memahami definisi keduanya dapat menimbulkan kepanikan yang berlebih. Jika lockdown diberlakukan, maka kekhawatiran warga bahwa mereka tidak dapat berbelanja kebutuhan seharihari, sehingga kebanyakan mereka membeli barang-barang dalam jumlah banyak di supermarket karena merasa panik. Namun faktanya di beberapa banyak negara, mereka sebetulnya masih dapat berbelanja maupun bekerja saat status lockdown diberlakukan, walaupun pergerakannya terpaksa dalam kondisi terbatas.

Di satu sisi, kebijakan yang sudah ditempuh oleh pemerintah Indonesia dalam penanganan Covid-19 dihadapkan dengan problema tersendiri, terutama dari masyarakat Indonesia sendiri. Layaknya gambaran kerangka berfikir yang sudah digambarkan sebelumnya, masyarakat tipe A kadangkala tidak memahami atau terkesan tidak mentaati aturan terkait Covid 19 tersebut. Beberapa bentuk ketidaktaatan masyarakat yang kerap kali dilakukan adalah tidak menerapkan 
social distancing dengan tetap melaksanakan kerumunan masa seperti kumpul di kafe, salat berjamaah di masjid padahal sudah ada fatwa MUI terkait hal tersebut dan kegiatan masa lainnya. Selain itu, pemerintah telah mewajibkan penggunaan masker bagi setiap warga, khususnya mereka yang akan menaiki kendaraan umum. Namun hal ini juga masih sering dilanggar oleh masyarakat.

Selanjutnya, atas situasi ini, banyak oknum mencoba memperkaya diri sendiri dengan menimbun barang-barang, salah satunya masker yang beredar di pasaran sehingga menjadi langka. Selain itu, banyakjuga terjadi tindak kriminal dengan memanfaatkan kondisi Indonesia di situasi Covid-19 ini. Ada oknum yang tidak bertanggungjawab yang mencuri masker, alat pelindung diri (APD), hand sanitizer dan benda-benda medis lainnya hanya untuk memperkaya diri sendiri. Larangan untuk mudik ke kampung halaman juga tidak diindahkan oleh beberapa kelompok masyarakat, padahal larangan tersebut adalah untuk mencegah penyebaran Covid 19. Tipikal masyarakat tipe A yang dijabarkan sebelumnya merupakan hambatan dalam menjalankan kebijakan yang ada. Tentunya dalam hal ini, Presiden Joko Widodo perlu berperan untuk menjaga keseimbangan kondisi sosial yang ada.

Demi menjaga kondisi sosial yang ada dan mengurangi efek domino atas permasalahan yang terjadi, maka Jokowi membuat beberapa kebijakan terbaru untuk mendukung perekonomian masyarakatnya. Layaknya artikel yang ditulis oleh Azanella (2020) bahwa Presiden RI bersama dengan kementerian dan lembaga terkait memberikan kompensasi biaya listrik. Pemerintah membebaskan biaya konsumsi listrik pada konsumen PLN dengan daya 450 VA selama tiga bulan, dimulai untuk biaya bulan April, Mei serta Juni. Selanjutnya, pengguna dengan daya sebesar $900 \mathrm{kwh}$ subsidi mendapat potongan sebanyak $50 \%$ dalam rentang bulan yang sama.

Presiden RI juga memberlakukan pembatasan sosial berskala besar dibandingkan menggunakan istilah lockdown. Meski sebelumnya masyarakat telah dihimbau agar menjaga jarak sosial maupun fisik, Presiden Jokowi merasa perlu memberlakukan imbauan tersebut untuk tetap diberlakukan. Presiden meminta agar pembatasan sosial berskala besar yang diberlakukan dapat diiringi dengan kebijakan darurat sipil. Payung hukumnya pun akan disiapkan agar pemerintah daerah dapat menerapkan kebijakan serupa di wilayahnya masing-masing.

Presiden turut mempertegas larangan yang tengah disusun peraturan terkait kegiatan mudik lebaran 2020. Kegiatan mudik bisa mengkhawatirkan karena berpotensi menambah sebaran Covid-19 ke daerah lainnya, sehingga akan sulit mengatasi wabah ini. Selain itu, ada kebijakan terkait dengan keringanan kredit bagi beberapa kalangan seperti pengemudi ojek online, supir taksi dan nelayan yang akan mendapat kelonggaran kredit kendaraan bermotor selama 1 tahun, terhitung dari April 2020.

Presiden RI dalam pemerintahannya menggelontorkan anggaran sebesar Rp 405,1 triliun guna memenuhi sejumlah kebutuhan di tengah pandemi Covid-19. Akan tetapi, anggaran tersebut saat ini berubah menjadi sebesar Rp. 695, 2 triliun dengan perubahan APBN 2020 melalui Perpres No. 54 Tahun 2020. Dari besaran Rp. 695,2 triliun tersebut, Pemerintah Pusat mengucurkan dana pada sektor kesehatan sebagai prioritas untuk dukungan pada tenaga kesehatan terutama pembelian Alat Pelindung Diri, pembelian 
alat-alat test kit, ventilator, dan sebagainya. Hal ini termasuk perkuatan daya rumah sakit rujukan termasuk wisma atlet, insentif dokter, perawat dan tenaga rumah sakit maupun santunan kematian pada tenaga medis. Setidaknya, sebanyak Rp 87,55 triliun akan dikhususkan untuk belanja pada ranah kesehatan, $\mathrm{Rp}$ 123,46 triliun untuk sektor UMKM, Rp 203,9 trilliun dialokasikan pada perlindungan sosial, Rp. 120,61 triliun untuk insentif dunia usaha, Rp. 53,57 triliun bagi pendanaan korporasi BUMN dan korporasi padat karya serta Rp. 106,11 triliun untuk dukungan sektor K/L dan Pemda. Dana lebih lain akan diperuntukkan pada pembiayaan program pemulihan ekonomi nasional (Fauzia, 2020). Namun demikian, Agustiyani (2020) menyatakan jika serapan anggaran penanganan Covid-19 masih dinilai rendah. Sebagai contoh, penyerapan anggaran sektor Kesehatan Covid-19 baru mencapai 5,12\% dari total alokasi Rp. 87,55 triliun. Hal ini menandakan bahwa pemerintah masih cukup hati-hati dalam pencairan dana, namun juga dibutuhkan semacam mekanisme kilat guna pencairan dana pada sector yang urgent untuk ditangani agar penanganan Covid-19 dapat dirasakan oleh masyarakat dengan maksimal.

Selain itu, untuk memperketat arus kedatangan turis ke Indonesia, Kemelu RI mengumumkan aturan terkait larangan mengunjungi dan transit ke Indonesia, bagi para pendatang yang dalam beberapa minggu terakhir melakukan perjalanan di wilayahwilayah, seperti Teheran, Qom, Gilan di Iran, Emilia Romagna, Marche dan Piedmont di Italia, serta Kota Daegu dan Propinsi Gyeongsangbuk-do di Korea Selatan. Panduan skema kebijakan Penanggulangan Bencana Covid 19 dapat diikuti penjelasan di bawah ini.
Pertama, legislasi. Pada komponen legislasi, penyusunan Peraturan Pemerintah yang mengatur penanggulangan bencana Covid 19 dari tingkat terendah yang dikonsep dan disahkan. Pengesahan ini penting direalisasikan agar pelaksanaan di lapangan memiliki dasar yang legal. Salah satu contoh yang sudah dikeluarkan selain, UU No. 24 tahun 2007 tentang Penanggulangan Bencana, adalah Perpres Nomor 17 Tahun 2018 tentang Penyelenggaraan Penanggulangan Bencana dalam Keadaan Tertentu, Keppres No. 11 tahun 2020 tentang Status Kedaruratan Kesehatan Masyarakat dan Keppres No. 12 tahun 2020 tentang Penetapan Bencana NonAlam Penyebaran Covid-19 sebagai Bencana Nasional yang didukung dengan peraturan dari kementerian maupun lembaga terkait untuk mendukung aplikasi aturan yang sudah ditetapkan.

Tercantum pada UU No. 24 tahun 2007, pemerintah beserta pemda berperan sebagai penanggung jawab dalam penyelenggaraan penanggulangan bencana. Dijelaskan bahwa siapapun berhak memperoleh pelindungan sosial maupun rasa aman, khususnya bagi sejumlah masyarakat terdampak bencana, hak mereka untuk memperoleh pelatihan, pendidikan serta keterampilan dalam penanggulangan bencana, memperoleh informasi secara tertulis maupun lisan terkait kebijakan penanggulangan bencana, berperan serta dalam merencanakan, mengoperasikan, dan memelihara program ketersediaan bantuan pelayanan sektor kesehatan. Hal ini juga termasuk berhak memperoleh dukungan psikososial, ikut serta dalam pengambilan keputusan terhadap kegiatan penanggulangan termasuk dalam pengawasan berlandaskan mekanisme yang telah diatur. Setiap orang yang terdampak bencana pun berhak atas 
bantuan kebutuhan dasar pokok, memperoleh ganti rugi karena dampak bencana yang disebabkan karena kegagalan konstruksi.

Upaya penanggulangan bencana adalah satu dari beberapa sektor pembangunan nasional yakni serangkaian kegiatan penanggulangan bencana pra, pada saat maupun pasca bencana. Selain itu, masih terdapat kelemahan dalam penerapan penaggulangan bencana maupun landasan hukum yang mendukungnya. Mempertimbangkan hal-hal tersebut di atas, maka disusunlah UU tentang Penanggulangan Bencana yang utamanya mengatur upaya menghadapi bencana meliputi pra bencana, tanggap darurat dan pasca bencana.

Terkait dengan pandemi Covid 19 ini, maka ini termasuk sebagai bencana non-alam, dimana Pasal 6 huruf a dan b UU Nomor 24 Tahun 2007 tentang Penanggulangan Bencana mendeskripsikan bahwa tanggung jawab pemerintah dalam penanggulangan bencana, pengurangan risiko bencana dan memadukan pengurangan risiko bencana dengan program pembangunan. Selain itu, dilaksanakan perlindungan bagi masyarakat yang terdampak bencana.

Dalam Keppres No. 12 tahun 2020, ada empat penekanan yang membahas penetapan Covid-19 sebagai bencana nasional, yaitu (1). Menegaskan bahwa kondisi Indonesia yang menghadapai bencana nonalam yang disebabkan oleh penyebaran Covid-19 sebagai bencana nasional. (2). Menentukan bahwa penanggulangan bencana nasional tersebut dilaksanakan oleh Gugus Tugas Percepatan Penanganan Covid-19 sesuai dengan Kepres Nomor 7 Tahun 2020 tentang Gugus Tugas Percepatan Penanganan Covid-19, yang telah diubah menjadi Kepres Nomor 9 Tahun 2020 tentang Perubahan atas Kepres Nomor 7 Tahun 2020 tentang
Gugus Tugas Percepatan Penanganan Covid-19. Hal ini dilaksanakan dengan sinergi antar K/L dan Pemda. (3). Perintah untuk gubernur, bupati dan walikota sebagai Ketua Gugus Tugas Percepatan Penanganan Covid-19 di daerah, untuk menetapkan kebijakan di daerah masing-masing dengan mempertimbangkan kebijakan Pemerintah Pusat dan (4). Keputusan tersebut mulai berlaku pada tanggal 13 April 2020. Sebagai tindak lanjut dari Keppres ini, selanjutnya Kementerian Dalam Negeri mengeluarkan Surat Edaran dengan Nomor: 440/2622/SJ Tahun 2020 tentang Pembentukan Gugus Tugas Percepatan Penanangan Covid-19 di daerah lengkap dengan penerbitan Pedoman Umum Menghadapi Pandemi Covid-19 bagi Pemda yang berisikan tahapan pencegahan, pengendalian, diagnosis dan manajemen sebagai patokan pemerintah daerah.

Kedua, perencanaan dan implementasi strategi. Penyusunan rencana Penanggulangan Bencana Covid 19 dimulai dari penyusunan situation report, rencana kebutuhan, hingga rencana aksi yang tersusun rapi bersamaan dengan pembentukan satuan tugas Penanggulangan Bencana Covid 19. Salah satu contoh yang sudah dikeluarkan adalah Keputusan Ka BNPB Nomor 9 Tahun 2020 tentang Penetapan Status Keadaan Tertentu Darurat Bencana dalam Wabah Penyakit Akibat Covid-19 di Indonesia.

Terdapat komitmen global dalam menghadapi ancaman yang menggangu kesehatan, yang dimulai dari IHR 2005 dengan 8 kapasitas inti dan meliputi 3 bahaya potensial. Untuk percepatan dan penguatan implementasi IHR 2005 tersebut, dibuat kesepakatan Global Health Security Agenda (GHSA) dengan implementasi paket 11 aksi global (lihat gambar 2). 
Semua kegiatan implementasi IHR 2005 dan GHSA bermuara pada kegiatan Detect, Prevent, dan Respond. IHR (2005) itu sendiri diperuntukkan pada upaya mencegah, melindungi dan mengendalikan penyebaran penyakit lintas negara dengan tindakan sesuai dengan risiko kesehatan yang dihadapi tanpa menimbulkan gangguan yang berarti. Tentunya, dalam aplikasi 8 kapasitas utama yang disebutkan dalam IHR, memerlukan sistem infrastruktur kesehatan masyarakat yang adekuat yang berfungsi untuk pencegahan penyakit menular serta sistem kesehatan masyarakat yang efisien, sensitif dan memadai untuk mendeteksi maupun merespon penyakit baru pada fase epidemi dan penyakit yang belum terdeteksi.

Pada tahap implementasi, pemerintah Indonesia pada tahun 2019 melalui Kementerian Kesehatan RI telah menerbitkan Dokumen Rencana Aksi Nasional Ketahanan Kesehatan Indonesia 2020-2024 sebagai acuan dalam menghadapai kondisi kesehatan masyarakat Indonesia. Selain itu, terbitnya Inpres No. 4 tahun 2019 tentang Peningkatan Kemampuan dalam Mencegah, Mendeteksi dan Merespons Wabah penyakit, pandemi global dan kedaruratan nuklir, biologi

Gambar 2

Komitmen Global Dalam Menghadapi Ancaman Kesehatan

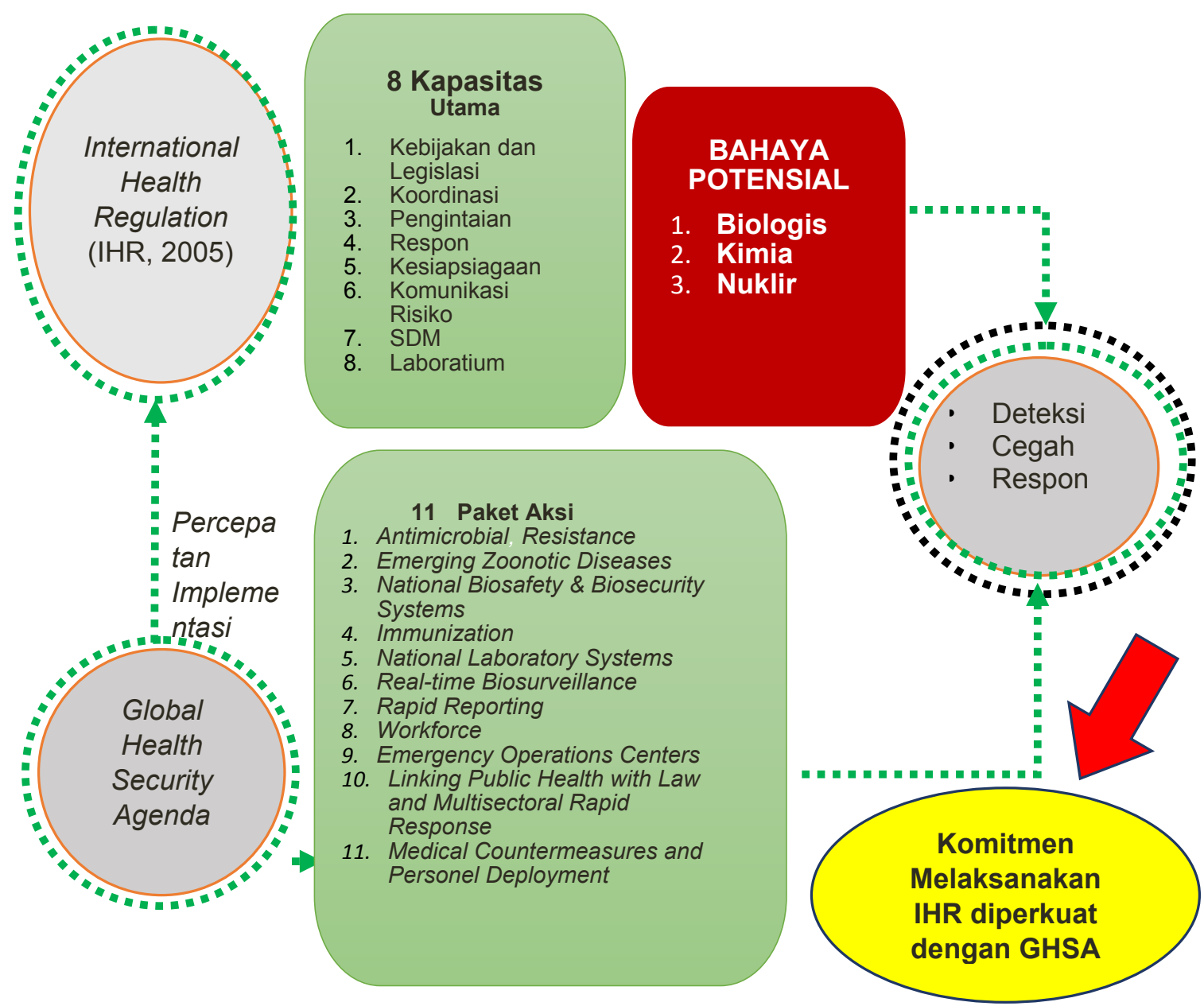

Sumber: Yurianto, 2020 
serta Kimia dirasa sesuai dengan kondisi Indonesia saat ini. Berdasarkan penjelasan ini juga, skema area kunci dalam pencegahan dan pengendalian penyakit menular dapat dijelaskan dalam gambar 3.

Berdasarkan ilustrasi pada gambar 3, baik pencegahan dan pengendalian penyakit menular dilaksanakan tahapan deteksi secara aktif maupun pasif, pencegahan faktor risiko dan spesifik serta respon dengan penyembuhan dan dukungan sesuai demgan anjuran yang sudah ditetapkan. Pencegahan dan penangkalan dapat dilaksanakan pada berbagai akses masuk ke Indonesia. Selain itu, hal ini juga didukung dengan kesiapan laboratorium, Rumah Sakit rujukan, alat deteksi cepat maupun pemberdayaan masyarakat dalam mendeteksi penyakit yang ada. Langkah pencegahan dimulai dari gerakan masyarakat hidup sehat dan peningkatan edukasi masyarakat mengenai Covid 19 dari berbagai media yang ada. Selain itu, penyedian call center untuk menerima keluhan, laporan dari masyarakat terkait dengan Covid-19 juga dirasa krusial. Pada akhirnya, respon pemerintah dengan tatalaksana kasus, penelusuran kontak, peningkatan komunikasi risiko, observasi kelompok berisiko, kekarantinaan dengan PSBB, social distancimg, physical distancing, isolasi maupun pencatatan dan pelaporan didukung oleh seluruh sektor terkait akan memberikan bentuk strategi Indonesia yang baik dalam penanganan Covid-19 ini. Dalam rangka mendukung strategi yang dicanangkan, pemerintah mengeluarkan PP No. 21 tahun 2020 tentang Pembatasan Sosial Berskala Besar (PSBB) dalam rangka Percepatan Penanganan Covid-19. Dalam peraturan ini, disebutkan bahwa PSBB harus memenuhi kriteria apabila jumlah kasus dan atau jumlah kematian akibat penyakit meningkat dan menyebar secara signifikan dan cepat ke beberapa wilayah, dan terdapat kaitan epidemiologis dengan kejadian serupa di wilayah atau negara lain.

Pada PSBB ini, paling tidak meliputi liburnya kegiatan sekolah dan lokasi kerja, pembatasan kegiatan ibadah, dan/ atau pembatasan kegiatan di tempat atau fasilitas umum. Namun demikian, yang harus diperhatikan pemerintah dalam implementasi PSBB ini adalah kebutuhan pendidikan yang akhirnya dilaksanakan dengan metode online, produktivitas kerja, dan ibadah

Gambar 3

Area Kunci Dalam Pencegahan Dan Pengendalian Penyakit Menular

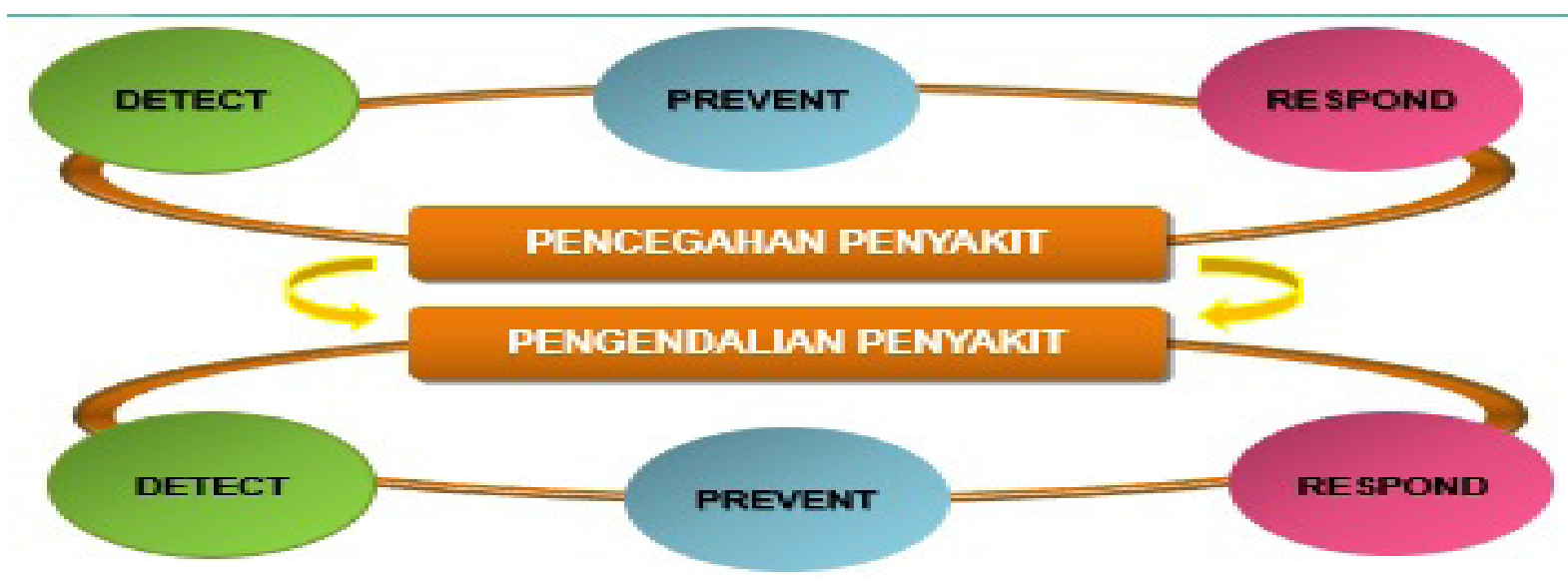

Sumber: Yurianto, 2020. 
penduduk. Oleh karena itu, pemerintah wajib memberikan stimulus ekonomi dalam mendukung penghidupan masyarakatnya yang terdampak Covid-19 ini yang dilaksanakan dalam mekanisme tertentu berupa bantuan uang, sembako, penjaminan ketersediaan stok bahan-bahan makanan maupun penegakan hukum pada oknum-oknum yang mengambil kesempatan dalam pandemi Covid-19 ini. Dalam hal PSBB ditetapkan oleh menteri yang melaksanakan urusan pemerintahan di bidang kesehatan, pemerintah daerah wajib melaksanakan dan mengacu pada ketentuan sebagaimana diatur dalam Undang-Undang Nomor 6 Tahun 2018 tentang Kekarantinaan Kesehatan. Pemberlakuan PSBB ini juga harus mempertimbangkan kesiapan daerah dalam hal terkait dengan ketersediaan kebutuhan hidup dasar warga, terbukanya sarana dan prasarana kesehatan, kecukupan anggaran dan penggunaan jaring pengaman sosial untuk masyarakat terdampak mencakup aspek keamanan.

Ketiga, kelembagaan. Penerbitan Instruksi Presiden untuk satuan tugas Penanggulangan Bencana Covid 19. BNPB melakukan langkah dengan membentuk Satgas Penanggulangan Bencana Covid-19 yang terlibat dalam tanggap darurat bencana lintas lembaga, diikuti dengan pengadaan perlengkapan yang memadai seperti rumah sakit, obat-obatan, dan sebagainya. Contoh Instruksi Presiden yang sudah dikeluarkan adalah Kepres RI Nomor 7 Tahun 2020 tentang Gugus Tugas Percepatan Penanganan Covid-19 sebagaimana telah diubah dengan Kepres RI Nomor 9 Tahun 2020 tentang Perubahan atas Keputusan Presiden Nomor 7 Tahun 2020 tentang Gugus Tugas Percepatan Penanganan Covid-19. Dalam gugus tugas ini, yang menjadi Ketua Pengarah adalah Menteri Koordinator Bidang Pembangunan Manusia dan Kebudayaan, dibantu oleh Menteri Koordinator Bidangan Politik, Hukum dan Keamanan sebagai wakil ketua. Untuk bidang pelaksana, Ka BNPB menjadi Ketua, dibantu oleh Sekretaris Jendereal Kementerian Kesehatan, Sekretaris Kementerian BUMN, Sekretaris Jenderal Wantannas, Asops Panglima TNI dan Asops Kepala Kepolisian Negara Republik Indonesia sebagai para wakil ketua bidang pelaksana. Kementerian dan lembaga terkait juga berpartisipasi mendukung gugus tugas tersebut sesuai ketugasannya (lihat gambar 4).

Selanjutnya, untuk menindaklanjuti Keppres tersebut, Kemendagri mengeluarkan Surat Edaran Mendagri No. 440/2622/SJ TAHUN 2020 tentang Pembentukan Gugus Tugas Percepatan Penanganan Covid-19 di daerah sesuai dengan ilustrasi pada gambar 4 tersebut.

Dalam skema yang dijelaskan pada gambar 4, peran pemerintah dapat berjalan dengan baik jika didukung oleh unsur-unsur terkait. Kolaborasi pentahelix berbasis komunitas yakni peran pemerintah, swasta, masyarakat, akademisi serta media sangat mendukung dalam penanganan Covid-19 di Indonesia. Narasi tunggal berbentuk edukasi, sosialisasi dan mitigasi perlu digencarkan dan dilaksanakan bersama-sama oleh tokoh masyarakat, tokoh agama, budayawan, partai politik hingga ketingkat daerah terkecil yang didukung oleh media yang edukatif serta informatif.

Keempat, pendanaan. Pemerintah Indonesia telah menganggarkan dana sebesar Rp. 695, 2 triliun pada revisi APBN 2020. Beberapa contoh implementasi penggunaan dana dalam Penanggulangan Bencana Covid-19 adalah Permendagri Nomor 20 Tahun 2020 tentang Percepatan Penanganan Covid-19 di Lingkungan Pemerintah Daerah dan Keputusan Ka BNPB Nomor 13 A 
Gambar 4

Gugus Tugas Percepatan Penanganan Covid-19 Di Indonesia

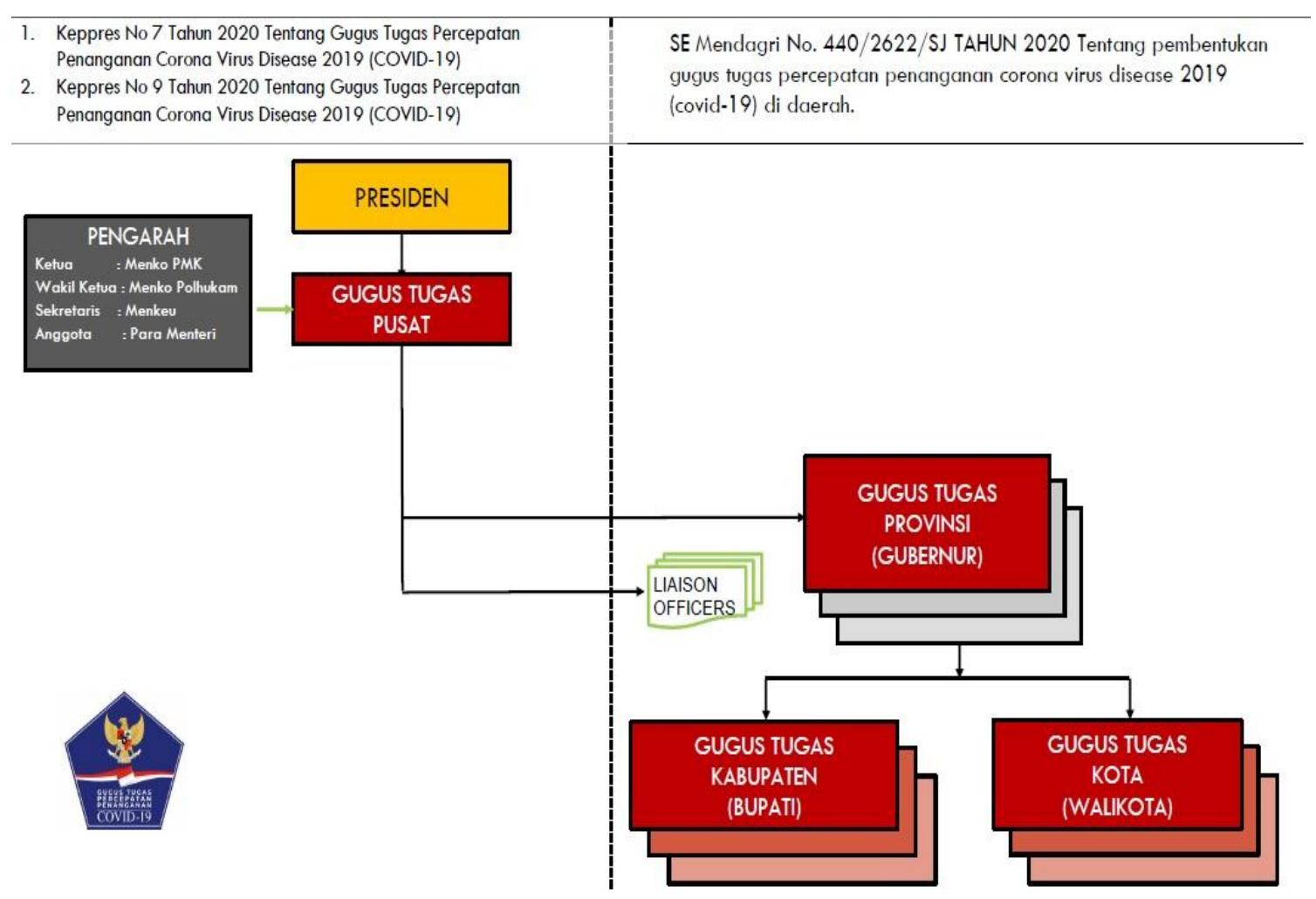

Sumber: Ruswandi, 2020

Tahun 2020 tentang Perpanjangan Status Keadaan Tertentu Darurat Bencana dalam Wabah Penyakit Akibat Virus Corona di Indonesia. Pada Keputusan Kepala BNPB dituliskan bahwa semua biaya yang digunakan sebagai akibat ditetapkan surat kepurusan ini dibebankan pada Dana Siap Pakai yang ada di BNPB. Selain itu, dalam KepresRI Nomor 9 Tahun 2020 tentang Perubahan atas Keputusan Presiden Nomor 7 Tahun 2020 tentang Gugus Tugas Percepatan Penanganan Covid-19 ditegaskan bahwa pendanaan dalam menangani pandemi ini dibebankan pada Anggaran Pendapatan dan Belanja Negara (APBN), Anggaran Pendapatan dan Belanja Daerah (APBD) maupunsumber lain yang sah dan tidak mengikat sesuai dengan ketentuan peraturan perundang-undangan.
Sebagai konsekuensinya, terjadi penyesuaian dalam anggaran kementerian dan lembaga, termasuk refocusing kegiatan dan realokasi anggaran demi penanganan Covid-19 di Indonesia. Hal sama berlaku juga di daerah, dimana revisi anggaran dilaksanakan bahkan sejumlah pemotongan anggaran diberlakukan untuk membantu penangangan Covid-19 ini. Melalui mekanisme tertentu juga, pemerintah Indonesia mendapatkan bantuan berupa dana maupun alat-alat kesehatan dari beberapa negara lain untuk penanganan Covid-19 di Indonesia. Selain itu juga, pandemi yang terjadi di Indonesia saat ini membuka peluang bagi para dermawan untuk saling membantu sesama dengan memberikan bantuan berupa uang, bahan makanan. alat pelindung kesehatan maupun bentuk-bentuk 
bantuan sosial lainnya bagi masyarakat yang terdampak Covid-19.

\section{Model Analisis Kebijakan Kelompok Dalam Kasus Covid-19 Di Indonesia}

Model kebijakan merupakan perwujudan sederhana tentang aspek-aspek dari suatu kondisi permasalahan yang disusun untuk beberapa tujuan tertentu. Seperti halnya masalah kebijakan yang berlandaskan pada konseptualisasi dan spesifikasi elemen-elemen kondisi masalah, model kebijakan ialah rekonstruksi artificial dari realitas dalam wilayah yang merentang dari ranah energi dan lingkungan hingga pada sektor kesejahteraan, kemiskinan maupun kejahatan.

Model ini dapat digambarkan sebagai konsep, grafik, diagram atau persamaan matematika. Mereka dapat dimanfaatkan bukan hanya untuk menerangkan, menjelaskan dan memprediksikan aspek masalah, namun juga untuk memperbaikinya dengan menyarankan serangkain upaya untuk memecahkan berbagai masalah tertentu (Hakim, 2020).

Selanjutnya, Simatupang (2003) menyatakan ada beberapa hal terkait dengan analisis kebijakan.

Pertama, analisis kebijakan adalah proses kegiatan sintesis informasi yang bermakna penggabungan sejumlah informasi, termasuk hasil penelitian, hingga didapatkan sebuah kesimpulan. Ini menandakan jika obyek analisis kebijakan adalah tahap penyusunan dari paket kebijakan. Kegiatan utama dalam analisis ini adalah mengumpulkan informasi secara runtut dan penarikan kesimpulan logis atas informasi tersebut. Dapat dipahami bahwa dalam analisis kebijakan mengacu pada kaidah ilmiah.

Kedua, satu dari beberapa sumber utama informasi yang dianalisis dalam kebijakan adalah hasil-hasil penelitian. Ini menandakan bahwa analisis kebijakan ialah proses pengolahan lanjutan dari banyak hasil penelitian yang ada agar dapat dipakai dalam pengambilan keputusan dan merancang kebijakan publik.

Ketiga, luaran analisis kebijakan adalah saran pilihan keputusan atau rancangan kebijakan publik. Ini menandakan bahwa luaran kebijakan dapat berbentuk nasihat atau petunjuk operasional mengenai bahan pengambilan keputusan publik. Analisis kebijakan layaknya disajikan secara jelas, padat, lengkap dan runtut.

Keempat, pengguna analisis kebijakan adalah pengambil keputusan kebijakan publik maupun kelompok kepentingan (interest groups) terhadap kebijakan yang ada. Pengguna analisis kebijakan yang bersifat spesifik dikarenakan berhubungan dengan luaran analisis kebijakan yang berupa masukan atas kebijakan publik.

Kelima, analisis kebijakan menitikberatkan pada klien (client oriented) dikarenakan implikasi dari sifat analisis kebijakan yang membuahkan masukan pada keputusan yang siap-guna bagi user nya. Jika tidak berorientasi klien, maka analisis kebijakan mungkin tidak dapat digunakan dengan baik. Ini menandakan bahwa analisis kebijakan harus berdasarkan pada pola dari, oleh dan untuk klien.

Satu dari beberapa bentuk penyederhanaan yang digunakan dalam membangun model analisis kebijakan ialah melalui penyederhanaan proses kebijakan sebagai sebuah proses yang terdiri atas langkahlangkah yang lebih kecil. Selain memecah proses kebijakan menjadi bagian yang lebih sederhana, modelling juga mensyaratkan keberadaan penjelasan yang rasional tentang hubungan antar bagian tersebut agar terbentuk sebuah proses kebijakan (Santoso, 2010). 
Pengelompokkan kebijakan menjadi bagian yang lebih sederhana dengan harapan kompleksitas atas kebijakan dapat dimaknai dalam bentuk yang lebih mudah. Analisis akan mudah dilakukan dengan membagi kebijakan menjadi bagian yang lebih kecil, analisis pun dapat memfokuskan perhatian pada bagian tertentu saja. Terutama model stagist yang menggambarkan proses kebijakan sebagai langkah yang terdiri atas sejumlah aktivitas yang lebih kecil dan berjalan dalam proses yang berurutan.

Penyederhanaan kebijakan dapat dilaksanakan dengan pembedahan struktur kebijakan seperti terdapat pada contoh model, analisis, kebijakan di gambar 5 .

Skema ini mengamati bahwa dalam kebijakan apapun, ada melekat tiga hal, yaitu substansi atau persoalan yang hendak diatasi, proses yang perlu dilakukan guna mengatasinya, dan konteks dimana upaya untuk mengatasi masalah tersebut berlangsung. Dari. bentuk sederhana ini dapat dihasilkan banyak model-model yang menjadi turunannya.

Salah satu model analisis kebijakan adalah model kelompok. Menurut Dye, dalam Wahab
(2008), bahwa model ini bertolak dari asumsi bahwa interaksi antar kelompok di masyarakat merupakan pusat perhatian politik. Individuindividu yang punya latar belakang kepentingan serupa biasanya akan bersatu baik secara formal maupun informal guna mendesakan kepentingannya pada pemerintah. Dalam skema ini, perilaku individu memiliki makna politik jika mereka bertindak sebagai bagian dari kepentingan kelompok.

Sebagai alat bantu analisis, model kelompok ini juga dimanfaatkan dalam meganalisis proses perumusan kebijakan publik dan dapat digunakan untuk menganalisa proses penerapannya. Model pluralis lebih mengacu pada kebijakan publik yang terbentuk atas pengaruh sub- sistem yang berada dalam sistem demokrasi. Dalam model ini, gagasan dapat bersifat parsitipatif dan berbasis komunitas untuk merumuskan kebijakan atau pengambilan kebijakan.

Dalam model ini, kebijakan publik lebih mengilustrasikan keseimbangan yang dicapai dalam perjuangan kelompok pada kurun waktu tertentu dan kebijakan publik menggambarkan kesimbangan pasca pihak-pihak tertentu

Gambar 5

Model Dimensi Kebijakan

DIMENSI KEBIJAKAN

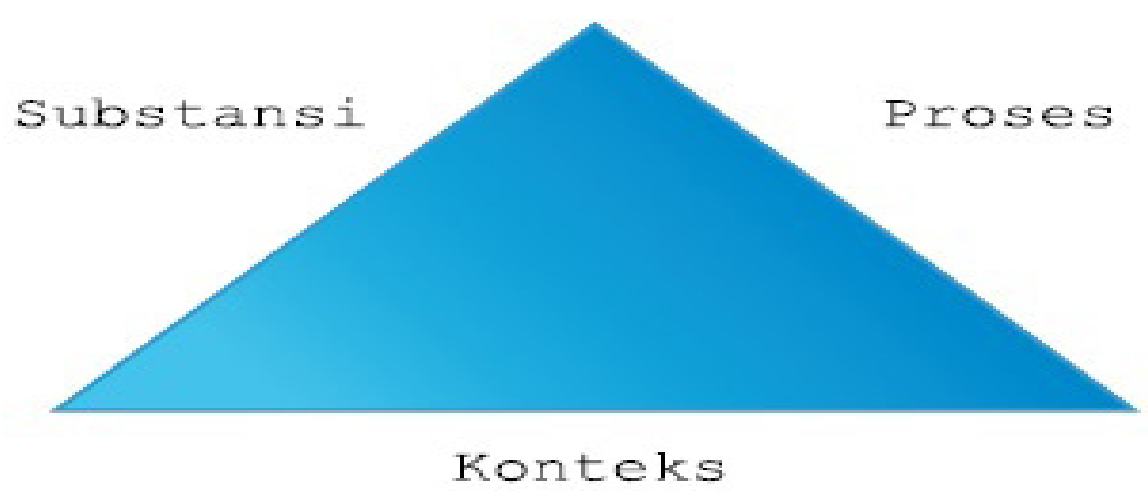

Sumber: Hupe dan Hill, 2006 
sukses mengarahkan kebijakan publik ke arah yang lebih menguntungkan. Besar kecilnya pengaruh dari sejumlah kelompok tersebut dapat berdampak sesuai dengan jumlah, kekayaan, kekuatan organisasi, kepemimpinan, akses terhadap pembuat keputusan dan kohesi dalam kelompok.

Selanjutnya, model kelompok ini juga dapat diasumsikan sebagai abstraksi dari proses pembuatan kebijakan dimana beberapa kelompok kepentingan berusaha mempengaruhi isi dan bentuk kebijakan secara simultan. Dengan demikian, pembuatan kebijakan terlihat sebagai upaya untuk menanggapai beberapa tuntutan dari berbagi kelompok kepentingan dengan cara tawar menawar, negosiasi maupun kompromi (lihat gambar 6).

Menyikapi penjabaran pada pembahasan sebelumnya, dapat dipahami bahwa peran Presiden RI bersama K/L dan masyarakat yang pro terhadap kebijakan pemerintah dalam pengangan Covid 19 menempatkan Presiden RI sendiri sebagai bentuk penyeimbang dari situasi terkini di Indonesia. Dalam hal ini, substansi kebijakan sudah mencoba mengakomodir semua kepentingan dari pihakpihak yang ada dalam kondisi ini, yakni pihak masyarakat dan instansi terkait. Konteks yang disisipkan dalam kebijakan pemerintah dalam penanganan Covid 19 ini adalah guna menjaga stabilitas ekonomi serta kondisi sosial masyarakat di tengah pandemi Covid 19. Proses yang dibutuhkan dalam hal ini membutuhkan kerja sama semua $\mathrm{K} / \mathrm{L}$ terkait, khususnya peran masyarakat itu sendiri dalam mencegah dan menghentikan rantai penyebaran Covid 19 di Indonesia.

Perjuangan pemerintah dalam menyelesaikan masalah pandemi covid 19 di Indonesia tidaklah mudah. Namun, langkah yang sudah diambil menurut peneliti merupakan langkah yang sudah mengakomodir semua pihak yang berkepentingan. Gambaran analisis kebijakan kelompok dalam penanganan Covid-19 di Indonesia ditunjukkan dalam gambar 7 .

\section{THE GROUP MODEL:}

Added Influence

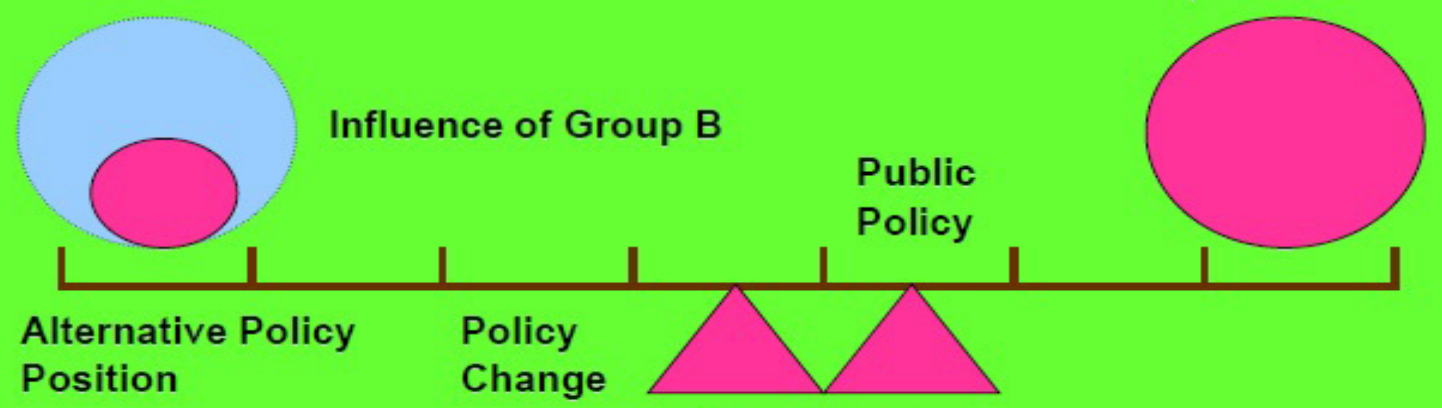

Equilibrium

Sumber: Wahab, 2008 


\section{Covid-19 Dalam Model Ketahanan Nasional Dan Hitungan Statistik Simulasi Opsi Pengambilan Kebijakan}

Kejadian atas tersebarnya Covid-19 ini menjadi urusan dunia internasional serta muncul sebagai masalah yang mengancam kondisi nasional Indonesia. Masalah maupun dampak dari Covid-19 di Indonesia, bagaimana negara Indonesia menghadapinya, dapat diamati melalui model ketahanan nasional Indonesia terkini, yaitu Astagatra. Menurut model ketahanan \nasional, aspek kehidupan nasional dibagi dua yaitu aspek alamiah dan aspek sosial. Aspek alamiah mencakup tiga gatra, yakni Kondisi Geografis negara, Keadaan dan Kemampuan Penduduk (Demografi) serta Kekayaan Alam. Maka, aspek alamiah dianggap mewakili tiga gatra, atau Trigatra.
Aspek sosial pun mencakup lima gatra, yakni Ideologi, Politik, Ekonomi, Sosial budaya serta Hankam (Pertahanan dan Keamanan). Oleh karenanya, lima gatra ini dimaknai sebagai Pancagatra.

Tergabungnya dua aspek tersebut membuahkan delapan gatra atau yang dikenal dengan istilah Astagatra (asta = delapan). Jika mengamati masalah Covid-19 saja, maka seolah-olah masalahnya hanya pada virus yang menyerang kesehatan manusia saja. Namun karena Covid- 19 ini sudah menjadi pandemi, maka ini pun menjadi masalah penyakit dan Kesehatan yang berkaitan dengan masalah sosial berdampak pada masalah lainnya.

Dilihat dari Astagatra, masalah kesehatan masyarakat dapat tercantum pada Aspek Sosial di Gatra Sosial / Budaya. Akan tetapi, jika dilihat dari kondisi terkini,

Model Analisis Kelompok Dalam Kebijakan Penanganan Covid 19

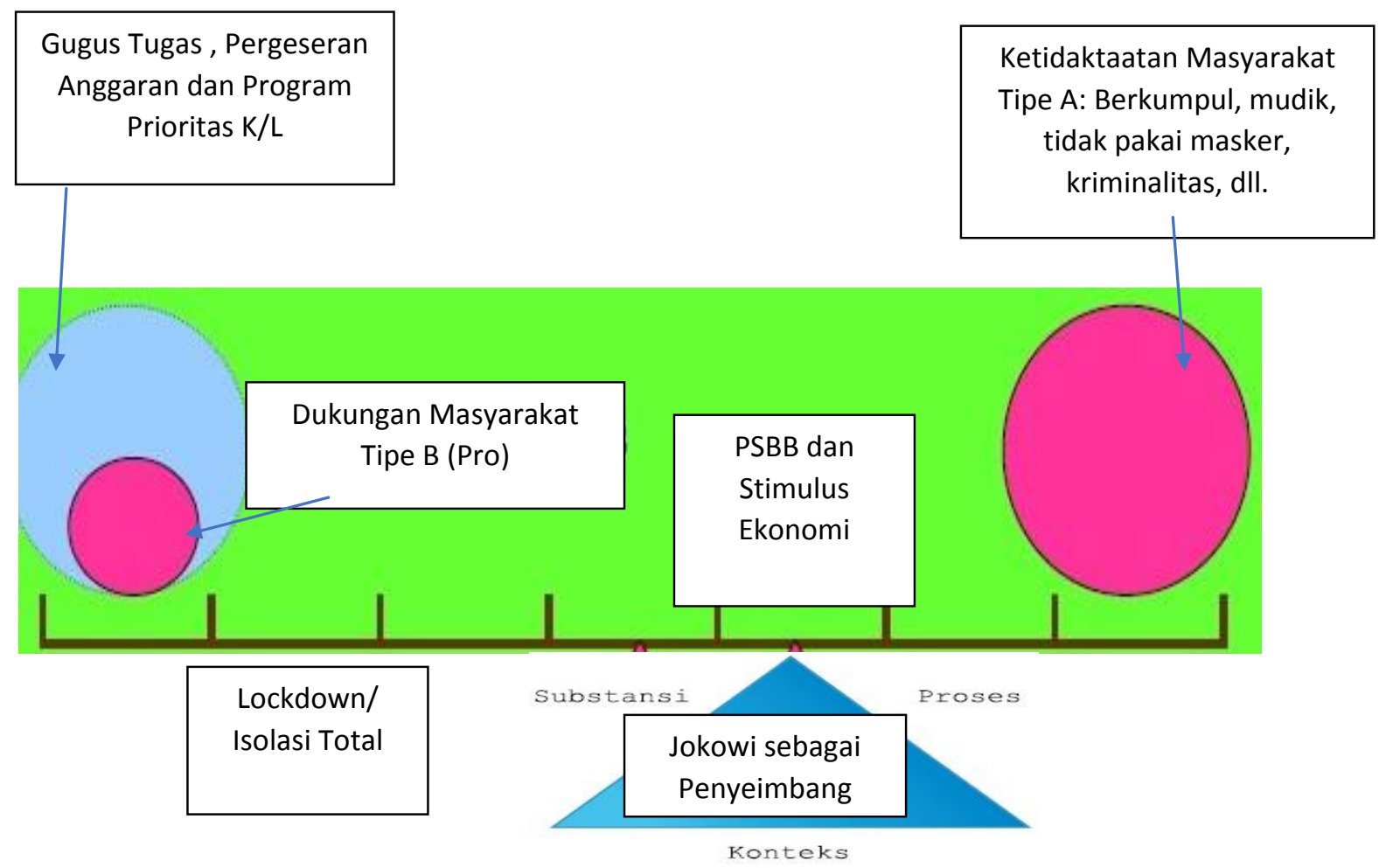

Sumber : Diadopsi dari Wahab, 2008. 
hal ini juga berdampak pada gatra lainnya. Mewabahnya virus ini di belahan negara lain sudah menggungcang perekonomian dunia dan Indonesia, maka ini menyerang Gatra Ekonomi. Keterlibatan instansi militer serta aparat keamanan lainnya juga sudah menyentuh Gatra Pertahanan dan Keamanan. Masukkan kritikan pada pemerintah atas lambannya atau salah dalam menyikapi Covid-19 juga sudah termasuk pada Gatra Politik. Selanjutnya, himbauan yang disampaikan agar tidak melakukan kegiatan keagamaan hingga ada yang mengasosiakan dengan ajaran komunis maka ini berkaitan dengan Gatra Ideologi.

Bila dilihat dari Aspek Alamiah maka Gatra Kondisi Geografis Indonesia yang terdiri dari banyak pulau dapat menguntungkan guna pencegahan menyebarnya Covid-19 dari satu pulau ke pulau lainnya dengan aturan yang ketat oleh pemerintah. Pada Gatra Kekayaan Alam, pemanfaatannya dapat terhambat dan tidak dapat dimanfaatkan oleh masyarakat apabila Covid-19 tidak segera diatasi. Dari Gatra Demografi, perlu dibuktikan kepada masyarakat bahwa pemerintah sudah sangat serius memimpin, memegang komando dan kendali penuh dalam perang melawan virus ini. Perlu diinformasikan kabar yang positif tentang upaya dan sejumlah aturan dalam menghadapi Covid-19 sehingga masyarakat dapat lebih paham dan merasa terlindungi. Selain itu, perlu dikobarkan semangat, sikap pantang menyerah dan rasa percaya diri bahwa bangsa Indonesia pasti mampu mengatasi wabah Covid-19 sedini mungkin. Masyarakat juga perlu diberdayakan agar tidak mudah panik dalam menghadapi situasi pandemi ini. Masyarakat harus dilatih kedisiplinan, patuh dan taat melaksanakan aturan dan himbauan dari pemerintah. Masyarakat juga harus mampu menjaga dirinya sendiri dan keluarga serta lingkungannya agar tidak terpapar Covid -19 .

Terkait dengan kondisi pandemi global Covid-19, Hamid (2020) menyatakan bahwa kapasitas kesehatan akan sangat bergantung pada kondisi tenaga kesehatan dan kesediaan logistik. Hal ini menjadi tuntutan nasional dalam rangka menyediakan logistik dan pekerja kesehatan lokal yang berkualitas dan berkompeten. Dijelaskan oleh Hamid (2020) juga bahwa kebijakan yang ada di Indonesia, seperti social distancing, tidak berkumpul pada tempat ibadah, tempat kerja maupun pembatasan sosial lainnya, menghadapi banyak tantangan, terutama dengan alasan perekonomian dan ajaran agama. Mahmud, dkk (2020) menambahkan bahwa Covid-19 juga menyebabkan adanya kekhawatiran dan depresi atas jenjang karir masa depan bagi sekelompok orang yang akhirnya menyebabkan efek negatif pada kondisi psikologi manusia tersebut. Pernyataan ini didukung oleh Ustun (2020) bahwa depresi akan Covid-19 ini lebih banyak dialami oleh wanita lajang berusia 18 s.d 29 tahun. Selain itu, kondisi yang memperburuk depresi adalah pemasukan ekonomi yang sedikit serta ketakutan akan terinfeksi dari orang lain. Dijelaskan pula bahwa orang yang memiliki kesibukan bersama keluarga, pendidikan atau bekerja di rumah memiliki taraf depresi yang lebih rendah dari yang lainnya. Dari penjelasan ini, dapat dipahami bahwa Covid-19 memberikan dampak negatif tidak hanya dari kesehatan klinis saja, tapi juga berdampak pada kesehatan psikologi manusia.

Chakraborty dan Maity (2020) memaparkan dalam artikelnya bahwa memang benar Covid-19 memberikan dampak pada kehidupan ekonomi manusia, maupun 
kesehatan masyarakat global. Memang secara signifikan memberikan dampak positif kepada lingkungan, karena pembatasan yang terjadi pada kegiatan industri sehingga menurunkan emisi gas buang yang berdampak pada lapisan ozon, namun kondisi ini di satu sisi memberikan dampak yang kurang baik pada kehidupan sosial, mengingat pemasukan ekonomi meraka terhenti. Dalam rangka kontrol maupun pencegahan ke depan, khususnya dalam menghadapi ancaman epidemi, memang diperlukan eksperimen dalam pembuatan vaksin dalam mencegah maupun mengobati penyakit yang ada. Selain itu, diperlukan reboisasi hutan guna mendukung pasukan oksigen dunia menjadi lebih baik dan sebagai sarana kehidupan bagi hewan-hewan liar agar tidak menciptakan virus yang berbahaya bagi manusia. Selanjutnya adalah menjaga atau mengontrol pertumbuhan populasi manusia dan menegakkan aturan yang kuat pada perlindungan hewan-hewan liar.

Ditambahkan oleh Totten (2015) yang menjelaskan hubungan epidemi dan keamanan nasional, bahwa benar dengan terjadinya epidemi dibutuhkan kebijakan untuk menghentikan kehadiran orang asing masuk ke suatu negara, kalaupun orang asing sudah masuk ke suatu negara mereka harus dikarantina dan menentukan keputusan presiden terkait dengan penghentian urusan imigrasi. Hal tersebut memang dibutuhkan untuk menekan angka penyebaran Covid-19 ataupun penyakit menginfeksi lainnya. Selain itu, dijelaskan bahwa epidemi memberikan dampak pada perekonomian dan kekuatan militer. Hal ini ditandai dengan SDM yang sakit dan tidak dapat berkontribusi pada perekonomian maupun sektor militer guna pertahanan negara.

Hal penting lainnya dikemukan oleh Torales, dkk (2020) bahwa pandemi Covid-19 memberikan dampak yang negatif pada kondisi mental dan kesehatan jiwa masyarakat. Wabah ini mengarah ke masalah kesehatan tambahan seperti stres, kecemasan, gejala depresi, insomnia, penolakan, kemarahan, dan ketakutan secara global. Kekhawatiran kolektif mempengaruhi perilaku sehari-hari, ekonomi, strategi pencegahan dan pengambilan keputusan dari pembuat kebijakan, organisasi kesehatan dan pusat kesehatan, yang dapat melemahkan strategi Covid-19 mengendalikan dan mengarah pada lebih banyak morbiditas dan kebutuhan kesehatan mental di tingkat global.

Bahkan, ketakutan akan hal yang tidak diketahui menyebabkan tingkat kecemasan yang lebih tinggi dibandingkan dengan orang sehat dan orang-orang dengan masalah mental yang sudah ada sebelumnya. Ketakutan publik yang tidak adil dapat menyebabkan diskriminasi, stigmatisasi dan kambing hitam (Mowbray, 2020). Pertama, respons emosional orang cenderung termasuk ketakutan ekstrim dan ketidakpastian, dan perilaku sosial negatif akan sering didorong oleh rasa takut dan persepsi risiko yang menyimpang. Kedua, upaya khusus harus diarahkan untuk populasi yang rentan, termasuk (1) yang terinfeksi dan sakit pasien, keluarga dan kolega mereka, (2) individu dan hubungan mereka dengan komunitas, (3) individu dengan kondisi medis yang sudah ada sebelumnya (baik fisik dan / atau mental), (4) penyedia layanan kesehatan, terutama perawat dan dokter yang bekerja secara langsung dengan orang yang sakit atau dikarantina. Akhirnya, tingkat stres psikologis yang sehat profesional dan orang lain mungkin menghadapi dan risiko rentan populasi harus dipertimbangkan dalam pengambilan keputusan krisis.

Oleh karena itu, kondisi mental masyarakat ke depan dalam menghadapi sebuah 
ancaman yang menghendaki mereka hidup dalam keterbatasan juga perlu diperhatikan. Kondisi mental yang tidak baik dapat memicu permasalahan lain yang juga sama berbahaya dengan ancaman sesungguhnya. Selain itu, kondisi pendidikan yang terkesan terhambat juga perlu ditanggulangi agar generasi penerus bangsa tidak kehilangan akal sehat, tidak kehilangan ilmu, kreativitas dan masa depan nya. Oleh karena itu, dalam mempersiapkan ancaman ke depan, perlu dipersiapkan protokol terkait kurikulum pendidikan dalam kondisi yang tidak memungkinkan. Hal ini bertujuan untuk menjamin pola pikir dan daya pemikiran generasi penerus agar tidak terjebak hanya pada ancaman yang melanda.

Gennaro, dkk (2020) memberikan pandangannya terkait dengan persepektif ke depan atas pendemi yang terjadi, bahwa Covid-19 yang menyangkut penyakit pernapasan akan lebih sulit berkembang, layaknya SARS, dalam situasi cuaca yang hangat. Maka dari itu, perubahan iklim, efek rumah kaca, imunitas serta kesehatan masyarakat akan berperan penting dalam penyebaran virus-virus yang ada. Ditambahkan oleh Singh dan Singh (2020) bahwa eksistensi manusia yang terbiasa dengan kehidupan sosial yang ada, menjadi terganggu akibat adanya Covid-19. Ketidakhadiran mekanisme hubungan sosial yang sehat berakibat pada kondisi individu yang mengalami kecemasan, stress, gangguan mental yang berdampak pada imunitas kesehatan masyarakat.

Dalam rangka melawan pandemi Covid -19 ini, tentunya pemerintah Indonesia memiliki skema simulasi kebijakan penanganan kasus tersebut. Dari beberapa opsi yang ada, ada 2 opsi kebijakan yang dapat dipilih, yakni Opsi C sebagai kebijakan rapid test, pengkarantinaan dan pembangunan rumah sakit khusus di pulau-pulau maupun wilayah terisolir. Masa persiapan selama 1 bulan yang terdiri atas proses pengecekan masal warga dengan rapid test kit, pembangunan rumah sakit khusus serta proses transport pasien menuju tiap-tiap lokasi rumah sakit. Proses karantina berlangsung selama 1,5 bulan dan memiliki persentase keberhasilan sebesar $20 \%$ dengan asumsi biaya yang dihabiskan adalah USD 800.000 (lihat tabel 1).

Kombinasi opsi selanjutnya yang dipilih adalah opsi D, yang merupakan kebijakan physical distancing dan juga work from home. Proses persiapan memakan waktu kurang hingga 1 minggu. Kebijakan ini memakan waktu sekitar setengah bulan dan mempunyai persentase keberhasilan sekitar 15\% dengan asumsi biaya USD 300.000 yang dihabiskan. Jika, semua kebijakan dimulai pada minggu pertama April 2020 dengan asumsi bahwa (!). Dana maksimal yang dialokasikan adalah USD 2.000.0000.000. (2). Negara X mempunyai penduduk sejumlah 5 juta orang; (3). Kasus awal Covid-19 pada negara X sejumlah 26 orang; (4). Persentase peningkatan kasus positif

Tabel 1

Opsi Kebijakan Beserta Keterangan Lain

\begin{tabular}{ccccc}
\hline Opsi & A & B & C & D \\
\hline Biaya & 900.0 & $\mathbf{1 , 2 0 0 . 0}$ & $\mathbf{8 0 0 . 0}$ & 300.0 \\
Masa Persiapan & 2 Minggu & 4 Bulan & 1 Bulan & $<1$ Minggu \\
Masa Pelaksanaan & 2 Minggu & 2 Minggu & 1,5 Bulan & 2 Minggu \\
Tingkat Kesuksesan & $25 \%$ & $\mathbf{9 5 \%}$ & $\mathbf{2 0 \%}$ & $15 \%$ \\
\hline & Lockdown & Vaksin & Rapid T & WFH \\
& Sumber: Diolah oleh Peneliti. & &
\end{tabular}


sebesar 26\% (berdasarkan referensi rata-rata peningkatan kasus covid-19 di Indonesia1); (5). Covid-19 mempunyai Case Fatality Rate (CFR) sebesar 2,3\%2; (6). Persentase kesembuhan dari pasien positif Covid-19 di negara X sebesar 6\% ; dan (7). Tingkat kesuksesan dari tiap opsi akan mengubah besaran dari persentase peningkatan kasus menjadi versi negatif dari persentase kesuksesan. Sebagai contoh apabila opsi C dieksekusi maka persentase peningkatan kasus akan berubah dari $26 \%$ menjadi $-20 \%$ dan paska eksekusi maka nilai persentase peningkatan kasus secara permanen akan turun. Rumus perhitungannya adalah nilai persentase kenaikan dikali sisa dari dari persentase keberhasilan. Pada contoh di atas maka formula yang digunakan adalah $\mathrm{P} 0=\mathrm{P} 1 \times \mathrm{x}(100 \%-\mathrm{S})$. (Keterangan: P0 $=$ persentase peningkatan kasus sebelumnya; $\mathrm{P} 1$ $=$ persentase peningkatan kasus baru; $\mathrm{S}=$ tingkat keberhasilan kebijakan sehingga paska eksekusi tingkat peningkatan kasus menjadi 21\%).

Berdasarkan asumsi yang telah dijabarkan, skema ajuan simulasi kebijakan terkait dengan penanganan Covid 19 di Indonesia dapat dihitung. Terkait dengan timeline penggunaan kombinasi kebijakan $\mathrm{C}$ dan D ditunjukkan dalam tabel 2 .

Selanjutnya, terkait dengan perhitungan kasus per hari dengan opsi C-DDDD ditunjukkan pada tabel 3 .

Tabel 2

Timeline Penggunaan Kombinasi Kebijakan C dan D

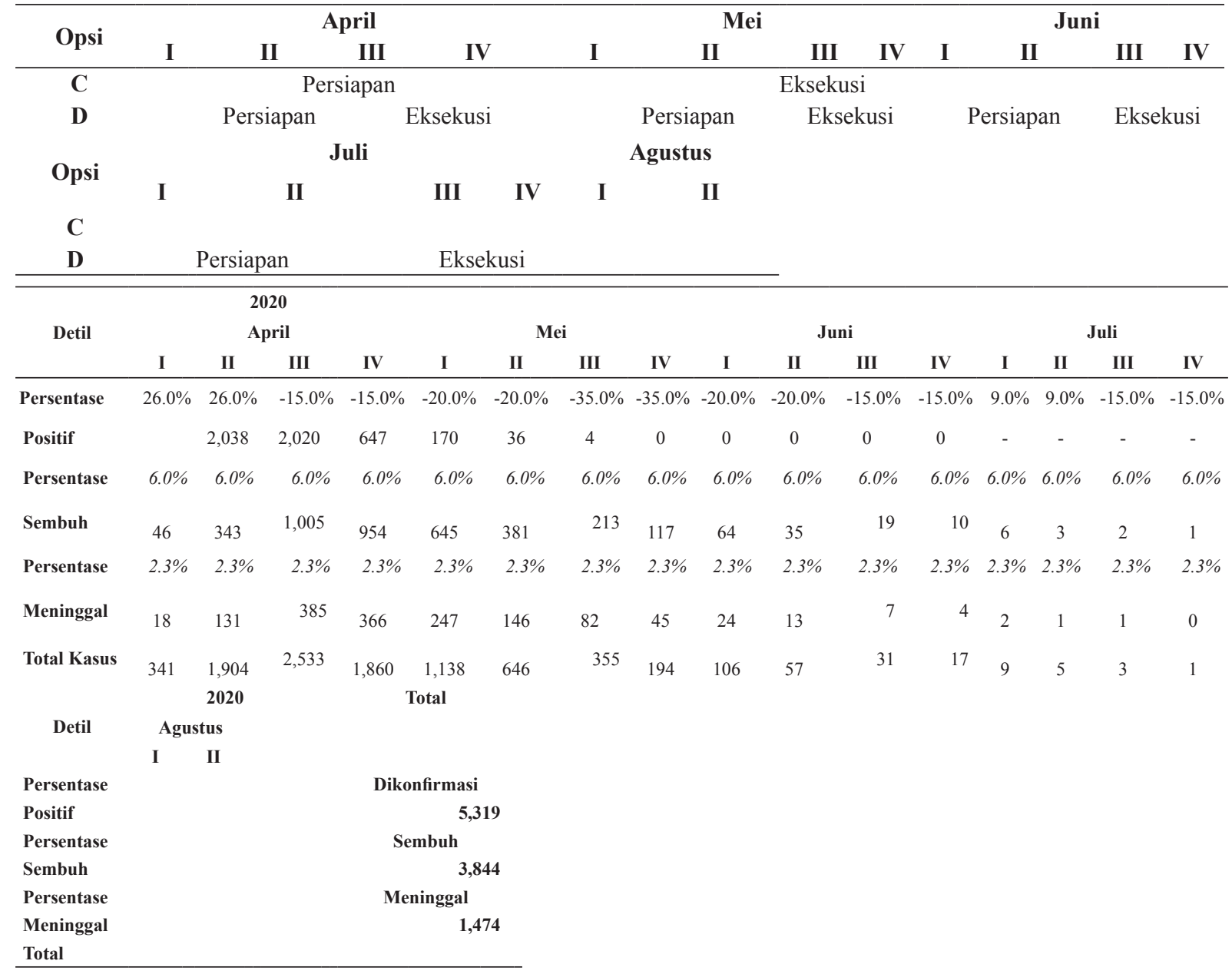

Sumber: Diolah oleh Peneliti 
Tabel 3

Perhitungan Kasus Per Hari Dengan Opsi C-DDDD

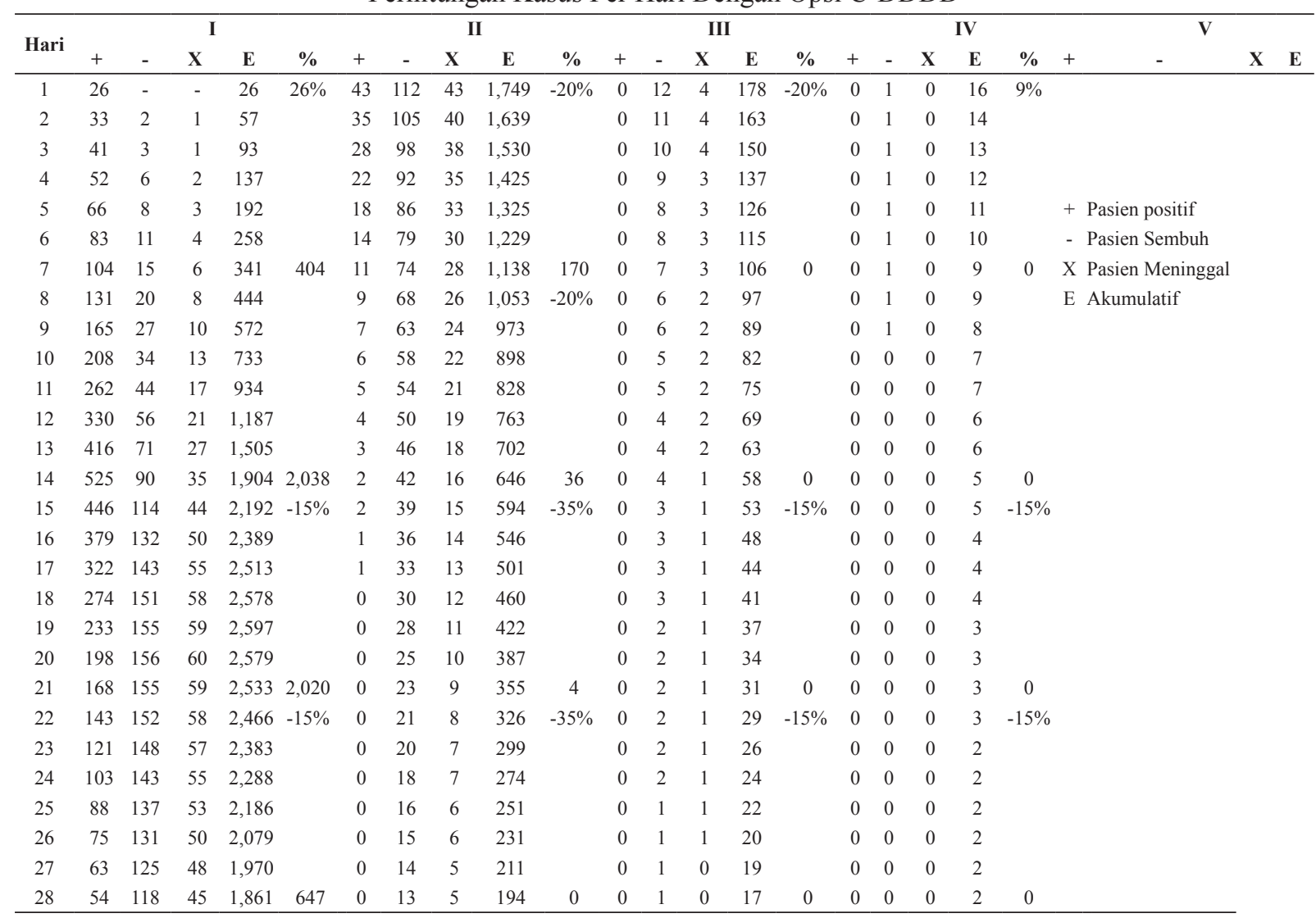

Sumber : Diolah oleh Peneliti

Berdasarkan jabaran sebelumnya, peneliti mengajukan Opsi C dan D dengan Kombinasi Kebijakan Opsi skema C-DDDD. Hal ini dapat dipahami bahwa opsi C (rapid test dll) dilaksanakan pada bulan Mei s.d pertengahan Juni diiringi dengan kebijakan opsi D di bulan April, Mei, Juni dan Juli secara simultan. Berdasarkan skema tersebut, korban positif Covid 19 akan berakhir pada akhir Mei dengan jumlah 0 orang. Secara keseluruhan, korban positif Covid 19 mencapai angka 5.319 orang, orang yang sembuh mencapai 3.844 orang dan orang yang meninggal mencapai 1.474 orang pada awal bulan Juli. Total biaya yang dihabiskan adalah USD 2.000.000.000 dengan asumsi bahwa opsi kebijakan yang dipakai akan selesai pada akhir bulan Juli dan pandemi ini berakhir pada bulan Agustus. Namun demikian, banyak opsi kebijakan lain yang sebetulnya dapat diambil selain opsi C-DDDD. Pada tabel 2, dapat diketahui bahwa setiap awal bulan, dari bulan April sampai dengan Juli, dinyatakan tidak ada dilaksanakan opsi kebijakan. Masyarakat diasumsikan akan tetap menjalankan prosedur social distancing selama Covid 19 sekaligus dalam rangka persiapan rapid test yang diajukan. Pada bulan Juli menuju bulan Agustus, opsi kebijakan social distancing memang tetap harus dilakukan untuk menjamin penyebaran virus telah selesai. Memang ada opsi untuk membuat anti virus dengan dana pemerintah, namun demikian sebetulnya, pembuatan anti virus sendiri dapat dilaksanakan oleh pihak-pihak akademisi di luar pemerintah, sehingga opsi pembuatan anti virus dapat dikesampingkan pada skema di atas. Sedangkan opsi lockdown 
tidak dipilih mengingat terlalu banyak dampak negatif yang akan ditimbulkan dan pemerintah bisa saja belum siap menghadapi efek domino dari lockdown tersebut.

\section{SIMPULAN}

Berdasar uraian tersebut di atas dapat ditarik simpulan sebagai berikut.

Pertama, Presiden RI bersama kementerian dan lembaga terkait telah berhasil memainkan peran sebagai penyeimbang dalam menghadapi pandemi Covid 19 di Indonesia. Kebijakan pemerintah yang sedang berjalan sudah menunjukkan keseriusannya dalam mengupayakan keselamatan dan kesejahteraan bangsa. Meskipun akan tetap banyak pihakpihak yang tidak bertanggungjawab dalam menentang maupun meragukan kebijakan yang ada, namun pemerintah akan tetap berupaya dalam mendukung segala kebutuhan yang ada.

Kedua, efek domino atas pandemi Covid 19 di Indonesia sangat perlu diwaspadai mengingat segala aktivitas masyarakat, mulai dari perekonomian, sosial, budaya, agama menjadi terbatas. Hal ini dapat mempengaruhi tingkat emosional masyarakat yang berdampak pada ancaman ketertiban sosial bahkan bersinggungan dengan keamanan nasional.

Ketiga, transparansi dalam penggunaan anggaran yang telah dialokasikan untuk penanganan Covid-19. Mengingat dana untuk penanganan Covid-19 yang cukup besar, maka transparansi dianggap penting karena untuk menjamin penggunaan dana tersebut tepat sasaran dan tidak dimanfaatkan oleh oknum aparat pemerintah yang tidak bertanggungjawab. Oleh karena itu, peran penyeimbang Presiden RI tidak hanya terbatas pada bentuk kebijakan saja, namun juga pada penyeimbang dalam menjamin terpenuhinya kesejahteraan dan rasa aman masyarakat.
Keempat, skema ajuan simulasi kebijakan pemerintah dalam penanganan Covid 19 menunjukkan hasil yang menjanjikan dalam penanganannya. Mekanisme rapid test dan protokol lanjutan lainnya dianggap penting untuk mendeteksi penyebaran Covid-19 di masyarakat agar dapat ditemukan solusinya. Ditambah dengan pemberlakuan PSBB atau dalam hal ini social and physical distancing, maka kebijakan yang ada akan mampu menekan angka penyebaran Covid-19 di Indonesia. Namun demikian, banyak opsi lain yang dapat dilaksanakan untuk penanganan Covid 19, salah satunya adalah dengan pembuatan antivirus dan lain sebagainya.

\section{DAFTAR PUSTAKA}

Agustiyani, 2020, Serapan Anggaran Covid-19 Rendah, Terawan: Berarti Pasien Sedikit. Diakses di < https://katadata.co.id/ agustiyanti/finansial/5f0ee7b5a6431/ serapan-anggaran-covid-19-rendahterawan-berarti-pasien-sedikit pada 21 Juli 2020>.

Azanella, L.A., 2020, 5 Kebijakan Jokowi Tangani Covid -19, Gratiskan Listrik hingga Keringanan Kredit. Diakses di <https://www.kompas.com/tren/ $\mathrm{read} / 2020 / 04 / 01 / 160000765 / 5$-kebijakanjokowi-tangani-covid-19-gratiskan-tariflistrik-hingga pada 7 April 2020>.

Chakraborty, I dan P. Maity, 2020, Covid-19 Outbreak: Migration, effects on society, global environment and prevention. Science of the Total Environment. 728 (2020) 13882.

Fauzia, M., 2020, Kemenkeu Tegaskan Anggaran Penanganan Covid-19 Rp. 695,2 Triliun. Diakses di <https://money. kompas.com/read/2020/06/20/10 0200226/kemenkeu-tegaskan-anggaran- 
penanganan-covid-19-rp-695-2-triliun pada 16 Juli 2020>.

Gennaro, dkk., 2020, Coronavirus Diseases (COVID-19) Current Status and Future Perspective: A Narrative Review. International Journal of Environmental Research and Public Health. 2020, 17, 2690.

Hakim, R, N., 2020, UPDATE: Covid-19 di Indonesia Kini 2.738 Kasus, Bertambah 247. Diakses di $<$ https://nasional.kompas. $\mathrm{com} / \mathrm{read} / 2020 / 04 / 07 / 16145841 /$ update-covid-19-di-indonesia-kini2738-kasus-bertambah-247 pada 7 April 2020>.

Hamid, 2020, Social Responsibility of Medical Journal: a concern for COVID-19 Pandemic. Medical Journal of Indonesia, 2020, Vol. 29, No. 1.

Handayani, S., 2020, Update Sebaran Virus Corona di Indonesia Senin (25/5/2020): 16 Provinsi Catat 0 Kasus Baru. Diakses di $<$ https://ternate.tribunnews. com/2020/05/25/update-sebaran-viruscorona-di-indonesia-senin-255202016-provinsi-catat-0-kasus-baru pada 26 Mei 2020>.

Hupe, Peter J. dan J. Hill Michael, 2006, Three Action Levels of Governance: Reframing the Policy Process Beyond the Stages Model, Sage Publications

Mahmud, dkk., 2020, Does 'Fear of COVID-19' Trigger future carreer anxiety? An empirical investigation considering depression from Covid-19 as a mediator. International Journal of Society Psychiatry, Vol. I, No.11.

Mowbray, H. 2020. In Beijing, Coronavirus 2019-nVoV has created a siege mentality, British Medical Journal, 2020, h. 368. pada Seminar Online Bersama
Universitas Pertahanan pada 28 April 2020.

Santoso, P., 2010, Analisis Kebijakan Publik, Yogyakarta: Fakultas Ilmu Sosial dan Politik Universitas Gadjah Mada.

Simatupang, P., 2003, Analisis Kebijakan: Konsep dasar dan Prosedur Pelaksanaan. Analisis Kebijakan Pertanian, Vol. 1, No. 1 Maret 2003,hh. 1 - 21.

Singh, J dan J.Singh, 2020, Covid-19 and Its Impact on Society. Electronic Research Journal of Social Sciences and Humanities. Vol 2, Issue I. Jan-Mar 2020.

Torales, J. dkk., 2020, The Outbreak of COVID-19 Coronavirus and its impact on global mental health. International Journal of Social Psychiatry 2020, Vol. 66, No. 4, hh. 317-320

Totten, R, J., 2015, Epidemics, National Security and US immigration. Defense and Security Analysis, Vol. 31, No. 3, hh. 199-212.

Undang-Undang Nomor 24 Tahun 2007 Tentang Penanggulangan Bencana.

Ustun, 2020, Determining depression and related factors in a society affected by COVID-19 Pandemic. International Journal of Social Psychiatry. hh. 1-10, 2020.

Wahab, 2008, Pengantar Analisis Kebijakan Publik, Malang: UPT Penerbitan Universitas Muhammadyah Malang.

Wibowo, A., 2020, Update Kasus Corona di Indonesia. Diakses di $<$ https://www. covid19.go.id/ pada 26 April 2020>.

WHO, 2002, Disaster and Emergencies: Definition, Addis Ababa: EHA.

Yurianto, A., 2020, Sistem Pencegahan Wabah Covid-19 di Indonesia. Paparan, diberikan pada Seminar Online Bersama Universitas Pertahanan pada 28 April 2020. 